\title{
Factors contributing to nitrate contamination in a groundwater recharge area of the North China Plain
}

\author{
Shiqin Wang, ${ }^{1 *}$ Changyuan Tang, ${ }^{2 *}$ Xianfang Song, ${ }^{3}$ Ruiqiang Yuan, ${ }^{4}$ Zhiwei Han ${ }^{5}$ and Yun Pan ${ }^{6}$ \\ ${ }^{1}$ Key Laboratory of Agricultural Water Resources, Center for Agricultural Resources Research, Institute of Genetics and Developmental Biology, \\ Chinese Academy of Sciences, Shijiazhuang 050021, China \\ ${ }^{2}$ School of Environmental Science and Engineering, Sun Yat-sen University, Guangzhou, China \\ ${ }^{3}$ Key Laboratory of Water Cycle and Related Land Surface Processes, Institute of Geographic Sciences and Natural Resources Research, Chinese \\ Academy of Sciences, Beijing 100101, China \\ ${ }^{4}$ School of Environmental Sciences and Resources, Shanxi University, Taiyuan 030006, China \\ ${ }_{5}^{5}$ College of Resources and Environmental Engineering, Guizhou University, Guiyang 550025, China \\ ${ }^{6}$ College of Resources Environment and Tourism, Capital Normal University, Beijing 100048, China
}

\begin{abstract}
:
Nitrate contamination is a common problem in groundwater of the North China Plain (NCP) owing to overuse of fertilizers and discharge of wastewater. Accordingly, it is important to investigate nitrate contamination in recharge areas to understand the fate of nitrate in the plains area. In this study, the spatial and temporal distribution characteristics of nitrate and factors contributing to its sources and transformation in shallow groundwater of the Beiyishui River watershed, NCP, were analysed by a combination of multiple regression and multi-tracer methods. The nitrate concentration of $79 \%$ of the samples exceeded the natural environmental standard of $13.3 \mathrm{mg} \mathrm{l}^{-1}$, while that of $23 \%$ of the samples exceeded the World Health Organization (WHO) drinking water standard of $50 \mathrm{mgl}^{-1}$. Groundwater age estimation of the hill regions based on chlorofluorocarbons (CFCs) revealed a mix of young water from 1982 to 1990 and old, low CFC water. The analysis based on the variations in land use in past years revealed that part of the grassland was converted into woodland between 1980 and 1995; therefore, the land use at the recharge time was used to determine which surface conditions influence groundwater nitrate concentrations. Multiple regression analysis showed that point source pollution contributed to the high concentration of nitrate in the hill region. Fertilizer application associated with land use change from grassland to woodland was also related to the present nitrate concentration. In the plains area, the contribution of fresh water from fault fractures and denitrification led to 31 to $72 \%$ and 6 to $51 \%$ reductions in nitrate concentrations, respectively. Our results suggested that controlling point source contamination and fertilizer input to hilly regions of the study will prevent groundwater of the plains area from deterioration in future years by mixing fresh water into the aquifers and decreasing denitrification, and therefore nitrate concentrations. Copyright (c) 2015 John Wiley \& Sons, Ltd.
\end{abstract}

KEY WORDS nitrate contamination; land use; CFCs; groundwater dating; North China Plain

Received 10 December 2013; Accepted 9 December 2015

\section{INTRODUCTION}

Nitrate contamination of groundwater is a worldwide problem that has caused a great deal of concern in many developed and developing countries (Dinnes et al., 2002). The WHO and the Council of the European Union have set a limit of $50 \mathrm{mg} \mathrm{NO}_{3}^{-} 1^{-1}$ for drinking water, and nitrate concentrations in groundwater in excess of this

*Correspondence to: Changyuan Tang, School of Environmental Science and Engineering, Sun Yat-sen University, No. 135, Xingang Xi Road, Guangzhou, China.

E-mail: cytang@ faculty.chiba-u.jp

Shiqin Wang, Key Laboratory of Agricultural Water Resources, Center for Agricultural Resources Research, Institute of Genetics and Developmental Biology, Chinese Academy of Sciences, 286 Huaizhong Road, Shijiazhuang 050021, China.

E-mail: sqwang@sjziam.ac.cn have the potential to cause health problems in animals and humans. Moreover, groundwater concentrations exceeding $13.3 \mathrm{mg} \mathrm{NO}_{3}{ }^{-} 1^{-1}$, which are considered to be the background value for many aquifers, may be indicative of contamination by anthropogenic activities (Burkart and Kolpin, 1993; Spalding and Exner, 1993; Eckhardt and Stackelberg, 1995).

The North China Plain (NCP), where groundwater is the major source of water for anthropogenic activities, contains $65 \%$ of China's agricultural land, but only $24 \%$ of its water (USDA, 2003). It has been suggested that rapid depletion of water resources will reduce China's grain production capacity, leading to massive grain shortages and the need for imports that will dominate world markets. Application of chemical fertilizer and animal manure has increased food production; however, overuse of fertilizers has resulted in contamination of surface water and 
groundwater (Kaneko et al., 2005). Additionally, increasing population and urbanization have resulted in increased wastewater production, which has accelerated nitrate contamination in groundwater around cities.

Some studies conducted in the NCP showed that more than half of all groundwater in the investigated regions had $\mathrm{NO}_{3}{ }^{-}$concentrations exceeding the limit of $44 \mathrm{mg} \mathrm{l}^{-1}$ for drinking water (Zhang et al., 1996). Nitrate contamination in some local shallow groundwater systems has also shown increasing trends (Zhu and Chen, 2002). For example, shallow groundwater in coastal areas of Laizhou Bay has undergone rapid increases in nitrate from tens of milligrams per litre in the late 1990s to hundreds of milligrams per litre in 2007 (Currell et al., 2012). Nitrate concentrations in a recharge area along the western side of the plain, in the vicinity of Beijing and locally in other parts of the plain are much higher than in other regions (Chen et al., 2005). Nitrate concentrations above the natural background have also recently been observed in the deep confined aquifer (Currell et al., 2012). Owing to the widespread contamination caused by nitrate leakage, studies conducted to identify the source and fate of nitrate have primarily focused on agricultural and urban regions. Increasing nitrate concentrations were shown to be caused by a combination of wastewater irrigation and lateral groundwater flow in the alluvial fans of the NCP (Tang et al., 2004; Chen et al., 2006; Tang et al., 2006; Wang et al., 2013). An obvious denitrification effect caused by the high content of total organic carbon in wastewater has also been reported in other wastewater-influenced areas (Zhang et al., 2013; Wang et al., 2014). In agricultural regions, studies of groundwater nitrate have focused on the source and fate of nitrate, soil fertilizer analysis and assessment of the potential risk of nitrate leaching ( $\mathrm{Li}$ et al., 2008; Lie et al., 2010; Shen et al., 2011). These studies have identified different nitrate sources and fates in groundwater of the plains area, including the alluvial fans, cities and coastal areas. However, no studies of the mountain/hill areas of the western part of the NCP have been conducted to date. It has been suggested that the mountain area and the piedmont plain in the west are the major recharge regions of the alluvial fans and the plain area groundwater (Chen et al., 2004; Lu et al., 2008; Yuan et al., 2012). Accordingly, it is important to identify the distribution characteristics of nitrate in groundwater and its influencing factors in these areas to help prevent nitrate contamination of groundwater throughout the NCP.

The distribution of nitrate in groundwater can be explained by many factors, and regression analysis is commonly used to identify the contribution of different factors. Land use is the most important factor controlling the distribution of nitrate in groundwater because it determines the types and amounts of chemicals intro- duced at the land surface (McLay et al., 2001). Many previous studies have shown land use to be correlated with water quality (Gardner and Vogel, 2005; Kaown et al., 2007; Fenton et al., 2009; Cao et al., 2013). Other factors found to have significant impacts on nitrate concentrations include well depth (Gardner and Vogel, 2005), topography (Devito et al., 2000; Rashid and Voroney, 2005; Kaown et al., 2007) and distance from pollution source (Gardner and Vogel, 2005). In recent years, groundwater dating has greatly improved our understanding of anthropogenic impacts on groundwater. Owing to the residence time of groundwater, it is necessary to relate the present nitrate concentration with land use when groundwater recharge occurs. Estimates of groundwater age have been used in many studies to identify the impacts of past and present land use practices on water quality (MacDonald et al., 2003; Broers, 2004; Moore et al., 2006; Stadler et al., 2008; Cao et al., 2013; Kralic et al., 2014). The combination of environmental tracers (e.g. chemical ions, stable isotopes, groundwater dating tracers) can further enhance the ability to delineate nitrate sources and transformation processes in groundwater.

This study was conducted to determine the spatial and temporal distribution characteristics of nitrate in groundwater of the Beiyishui River watershed, which is a recharge area of the NCP, as well as to identify possible factors contributing to the occurrence and transformation of nitrate in shallow groundwater in this region. We considered the recharge time of groundwater and historical land use during the recharge time to analyse the impact of land use on nitrate in groundwater. CFC concentrations were employed to determine the groundwater age. A statistical method combining geochemical data and groundwater dating methods was employed to achieve these goals.

\section{SITE DESCRIPTION}

\section{General setting}

The study area is located in the west of the NCP (Figure 1), which is characterized by a semi-humid monsoon climate with cold, dry winters (DecemberMarch) and hot, humid summers (June-August) (Yuan et al., 2011). Based on data collected by a weather station at the Chongling experimental site in the hill area, the perennial mean precipitation and evaporation are $641 \mathrm{~mm}$ and $1906 \mathrm{~mm}$, respectively. The perennial mean precipitation in the plains area ranges from 500 to $600 \mathrm{~mm}, 70 \%$ of which occurs from June to August (Figure 2 (a)). The Beiyishui River, which has a length of $59 \mathrm{~km}$, is the main tributary of the Juma River. Overpumping of groundwater in the NCP has resulted in 


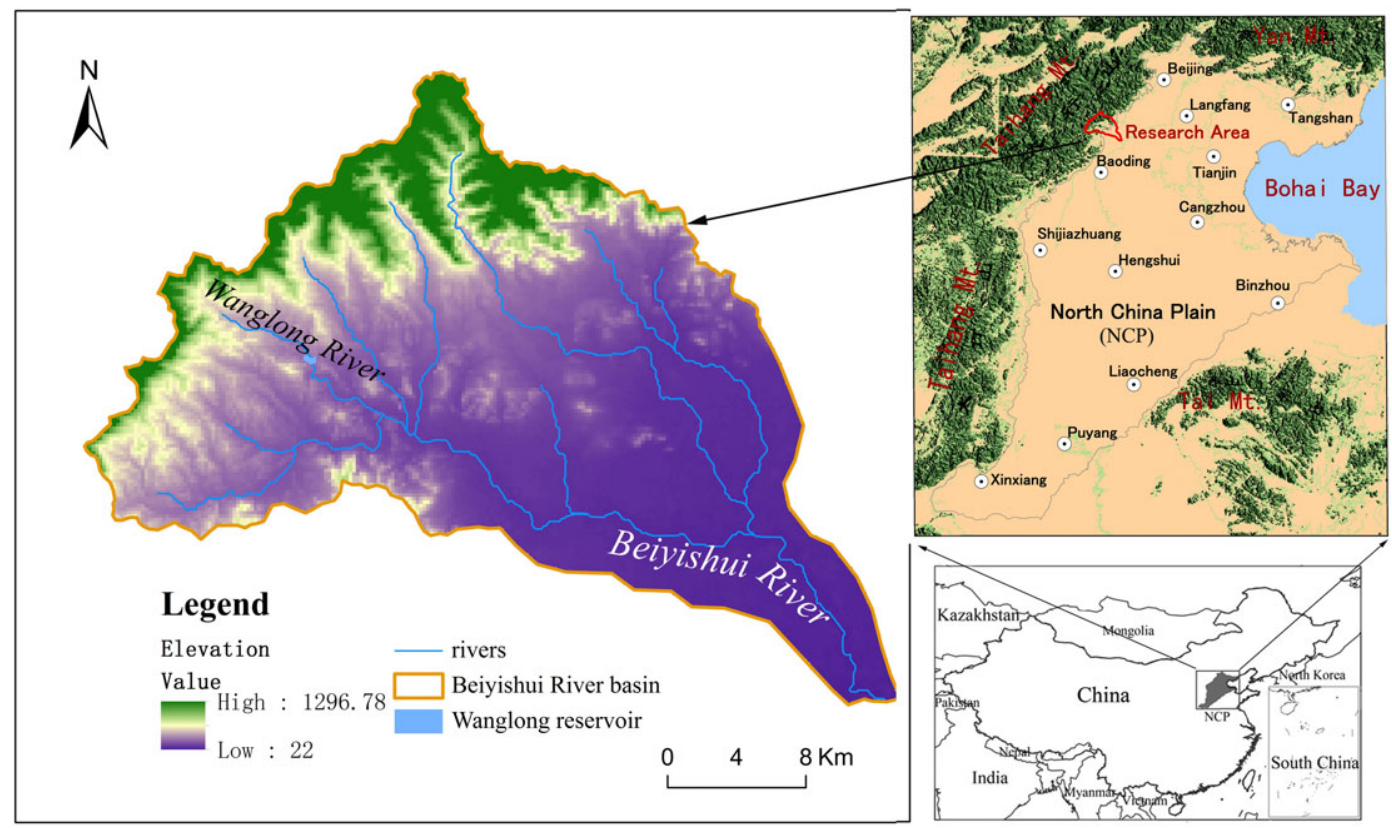

Figure 1. Location of the Beiyishui River watershed in the NCP
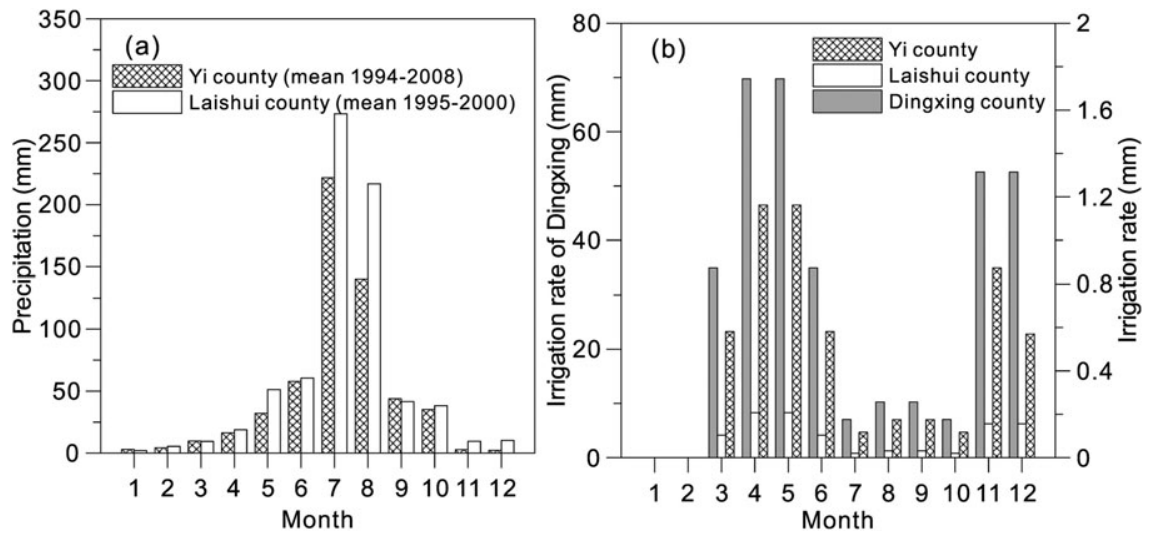

Figure 2. Monthly precipitation (a) and monthly irrigation rate (b) in several counties. The boundaries of the counties are shown in Figure 3

many rivers in the area drying up. However, rivers in the hill region are ephemeral because of the precipitation features. The Beiyishui River is an ephemeral river in the upper reach that is usually dry in the lower reach $(\mathrm{Xu}$, 2004). The Wanglong River is a tributary of the Beiyishui River that contains a constructed reservoir in the lower reach. The Beiyishui River watershed contains mountainous and hilly areas and a piedmont plain area with an altitude gradient of about $2 \%$ o that can be subdivided into a proluvial fan area and an alluvial fan/plains area (Yuan et al., 2011).

Groundwater in the study area is mainly used for irrigation, which accounts for $70 \%$ of the total water use. There are two dominant irrigation periods in the NCP, March to June and October to December. The irrigation rate increases from the upper reach (Yi and Laishui counties) to the lower reach (Dingxing county) (Figure 2 (b)).

\section{Hydrogeological characterization}

In the Beiyishui River watershed, the mountainous and hilly areas belong to the Taihang Mountain uplift, while the plains area is located in the Jizhong depression. The geology of the mountainous and hilly areas consists of calcite, granite, dolomite and a small amount of shale. Sandy loam and loess, which are the major soil components, are primarily distributed in the first-order/second-order terraces of rivers, while the aquifer consists of gravel in the mountainous and hilly areas. The permeability is high $(0.38$ to $0.58 \mathrm{~mm} / \mathrm{min})$ owing to the loose soil texture (Min et al., 2012). The 
unconsolidated sediments of Quaternary Q4 comprise the main stratigraphy of the plains area (Zhang et al., 2009). The sediments include sand, clay or interbedded sand and clay. The groundwater flows from Northwest to Southeast.

\section{Land use}

Land use in the study is mainly composed of farmland, woodland, grassland and residential area. Farmlands are mainly found in the plains, accounting for $51 \%, 45 \%$ and $50 \%$ of the total area in 1980, 1995 and 2000, respectively. In the hilly area, farmland is mainly located in the river valleys. Winter-wheat and summer maize, which are the major crops in the plains area, receive $250-300 \mathrm{~kg} \mathrm{~N} \mathrm{ha}^{-1} \mathrm{yr}^{-1}$. Additionally, maize, walnut tree and orchard farms receive $150-200 \mathrm{~kg} \mathrm{Nha}^{-1} \mathrm{yr}^{-1}$. The percentage of woodland increased from $14 \%$ (1980) to $27 \%$ (1995), then decreased to $14 \%$ (2000) which is almost the same with the 1980 level. The variation of grassland area shows an inverse trend relative to that of woodland, decreasing from 29\% (1980) to 19\% (1995), then increasing to $29 \%$ (2000). A massive afforestation programme including the planting of commercial forest (e.g. orchards) was carried out in China after 1980, which led to a portion of grassland and farmland being replaced by woodland (Zhao, 2013). After 1995, conversion of orchards to farmland and cutting of wood led to the woodland area decreasing again. The residential area is mainly located in the plains area and showed a slight increasing trend from $1980(5 \%)$ to $1995(6 \%)$, then to 2000 (6\%). To sum up, land use of 1980, 1995 and 2000 showed that large variation of land use occurred from 1980 to 1995 , while the land use of 2000 is the same with that of 1980 in the hill area. There was almost no large change in farmland area in the plains region during this period. Therefore, Figure 3 only showed the land use of 1980 and 1995.

\section{METHODS}

Sampling and analytical procedures

A field survey and sampling were carried out four times in September 2008, June 2009, May 2010 and September 2011. Samples collected from 2008 to 2010 were obtained from the same points (B01-B23) (Figure 3). Among these, B06 was spring water, and B12 and B18 were river water samples. Samples collected in 2011 were mainly located in the hill region (yellow points in Figure 3). Among these, B25 and B28 were river water samples and B26 and B29 were groundwater samples collected along a tributary of the Wanglong River. Samples B01, B03, B04, B07 and B08 were collected from woodland areas dominated by walnut trees, orchards and poplars. Samples
B02, B26, B27 and B29 were collected from farmland. Other samples were all collected from farmhouses surrounded by farmland. The lithology of the hill region is granite and wells in this area are hand excavated by digging to the base rock or to a certain depth, while wells in the plains area are drilled boreholes. Dug wells in the hill region are made of stone and have a diameter of $1 \mathrm{~m}$, while those in the plains area are cement tubes with a diameter of $0.3 \mathrm{~m}$. Groundwater can flow into the wells from around their walls. Groundwater was collected after pumping for $5 \mathrm{~min}$ until the volume of the boreholes were refreshed by the newly inflow water.

The water table of groundwater was determined using a water level measuring ruler. The $\mathrm{pH}$, electrical conductivity (EC), oxidation-reduction potential (ORP) and temperature $(\mathrm{T})$ were measured in situ using a portable meter (WM-22EP, DKK, TOA Corporation of Japan). $\mathrm{HCO}_{3}{ }^{-}$concentration was measured by titration in situ. All samples were collected into 100-ml air-tight polyethylene vials that were then sealed with adhesive tape to reduce evaporation. The water samples were subsequently filtered through $0.45-\mu \mathrm{m}$ filters. Samples for major ions $\left(\mathrm{Na}^{+}, \mathrm{K}^{+}, \mathrm{Ca}^{2+}, \mathrm{Mg}^{2+}, \mathrm{Cl}^{-}, \mathrm{SO}_{4}{ }^{2-}\right.$, and $\left.\mathrm{NO}_{3}{ }^{-}\right)$were analysed by ion chromatography (Shimadzu LC-10AD, Japan) at Chiba University. Freeze and Cheery (1979) suggested that 5\% was a reasonable error limit for percentages of ion balance; therefore, this value was used to accept the analyses as valid in the present study.

CFCs were analysed according to Han et al. (2007). Briefly, CFCs in water samples were collected and purified using a purge and trap extraction system (Busenberg and Plummer, 2000). The purified CFCs were then analysed by gas chromatography (Shimadzu, GC-14B, Japan) at Chiba University. The uncertainty associated with CFCs analysis was approximately $1 \%$ for water equilibrated with the ambient atmosphere. Groundwater dating using CFCs was accomplished based on recharge year by comparing the calculated partial pressure of CFCs insolubility equilibrium of water samples with historical CFCs concentrations in local air (Plummer et al., 2006).

\section{Buffer zone diameter determination of land use}

Generally, a land use circular buffer zone around each piezometer was used to determine the land use area that contributes to groundwater quality (Fenton et al., 2009). The radius defining the buffer area used in previous studies varies from 200 to $2000 \mathrm{~m}$ (Barringer et al., 1990; Kolpin, 1997; Fenton et al., 2009). In this case, the geology and hydrogeology conditions vary from the hilly area to the proluvial fan and alluvial fan areas. Additionally, the buffer zone is largely affected by aquifer features such as hydraulic conductivity and thickness. There are two methods applied to calculate the buffer zone. As to the wells where aquifer features are 


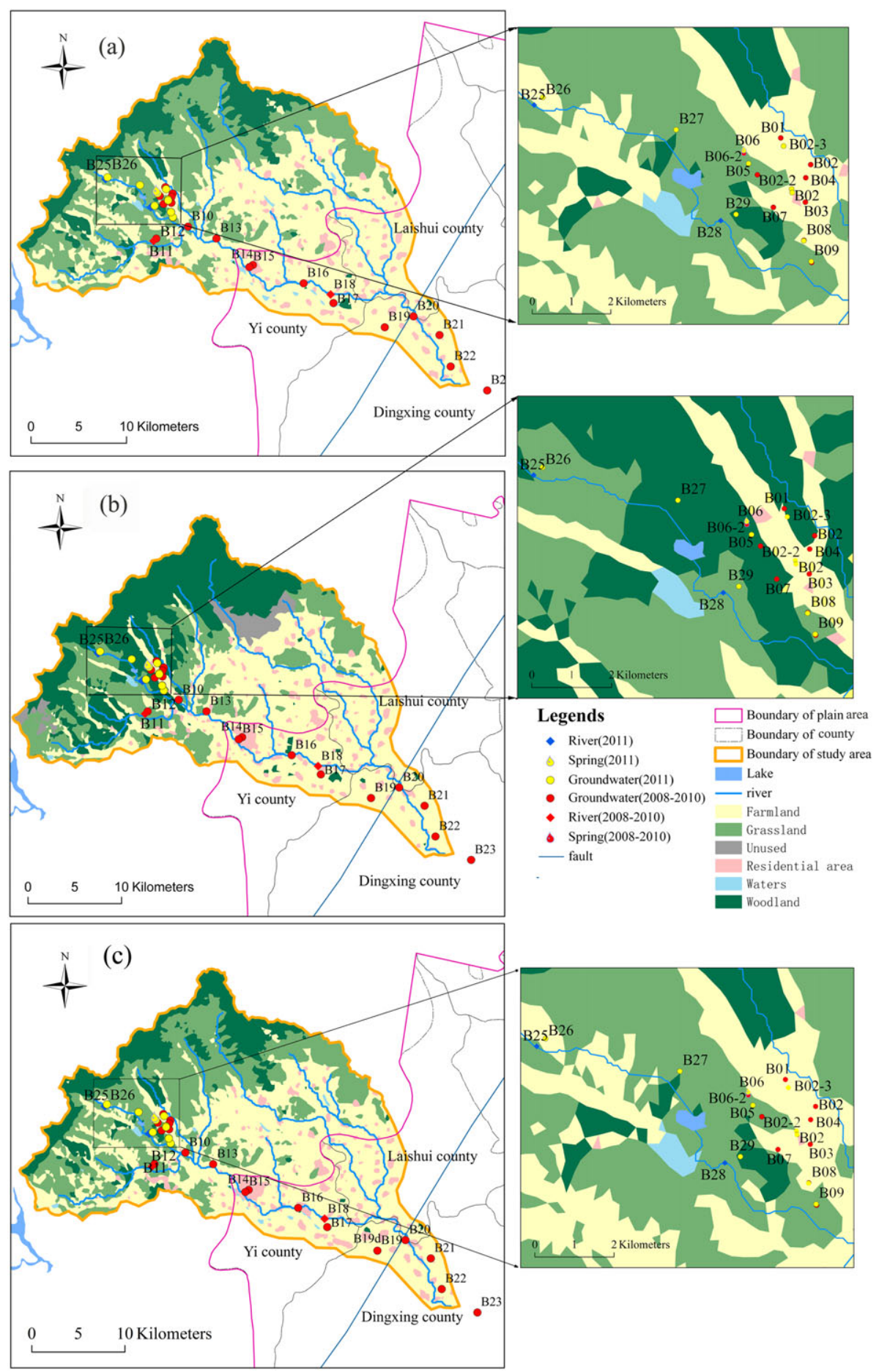

Figure 3. Position of water sampling and land use in 1980 (a), 1995 (b) and 2000 (c)

known, the diameter $\mathrm{D}(\mathrm{m})$ of the buffer zone in the direction of groundwater flow was approximated by:

$$
D=Q / b v
$$

where $b$ is the aquifer thickness, $v$ is the average effective Darcian linear velocity $\left(\mathrm{mday}^{-1}\right)$ and $Q$ is the quantity of water discharged $\left(\mathrm{m}^{3} \mathrm{day}^{-1}\right)$. The value of $v$ was calculated by:

$$
v=K_{\text {sat }} \frac{1}{\mathrm{n}} \frac{d h}{d x}
$$


where $K_{\text {sat }}$ is the saturated hydraulic conductivity and $n$ is the effective porosity.

The value of $Q$ was determined by (Darcy, 1856):

$$
Q=K_{\text {sat }} A \frac{d h}{d x}
$$

where $\mathrm{A}=b w, w$ is the aquifer width (m) and $\frac{d h}{d x}$ is the hydraulic gradient. The well in each site was taken as the centre of the buffer area, and the percentage of land use within the entire buffer zone was calculated. For samples such as B10 and B13, which were collected from the Quaternary sediments of the wide river valley, the radius of the buffer area was determined using Equations 1-3. In this calculation, the average hydraulic gradient was 0.0004 according to a field survey of the water table. The buffer radius was calculated using $K_{\text {sat }}=300-500 \mathrm{~m} \mathrm{day}^{-1}$ based on parameters of similar aquifer sediments of gravel in the plains area (Zhang et al., 2009), an effective porosity $n=0.30-0.33$ (Gao, 2005) and an average aquifer thickness of $20-40 \mathrm{~m}$. The calculated radii ranged from 750 to $1000 \mathrm{~m}$.

However, it was difficult to calculate the buffer radius in the fissured aquifer of hilly area because there was limited data describing the aquifer features; therefore, the positions of the sampling sites were considered. In areas in which groundwater flow direction was known, the buffer zone was extended to a groundwater divide. For example, samples B26 and B27 were collected from wells in the hillside, where the buffer zone was defined as the area surrounding the well and encompassed all areas or features that supply groundwater recharge to the piezometer up the hydraulic gradient to the groundwater divide in the Digital Elevation Model (Figure 4 (a)), then the percentage of land use area was calculated in the recharge area or the buffer zone (Figure 4 (b)). The recharge area was defined using the spatial tools of ArcGIS.

Land use maps for 1980, 1995 and 2000 were used to estimate the land use types at the recharge time of the young water by the linear interpolation method (Cao et al., 2013):

$$
\begin{aligned}
S_{i, j}\left(T_{r e}\right)= & S_{i, j}\left(T_{\text {start }}\right) \\
& +\frac{T_{r e}-T_{\text {start }}}{T_{\text {end }}-T_{\text {start }}}\left[S_{i, j}\left(T_{\text {end }}\right)-S_{i, j}\left(T_{\text {start }}\right)\right]
\end{aligned}
$$

where $S_{i, j}(T)$ is the area of the $i$ th $(i=1,2, \ldots, 8)$ land use type for sampling point $j(j=1,2, \ldots, 23)$ at time $T$; $T_{\text {start }}$ and $T_{\text {end }}$ give the two endpoints of each period (1980-1995; 1995-2000); and $T_{r e}$ is the recharge time of young water.

\section{Material balance method}

The water composition which recharge into the groundwater is one of the reasons for accounting for the water quality. Mixing of different waters can change the groundwater quality. A simple material balance model (Wang et al., 2014) was applied to calculate the nitrate concentration mixed by different recharge source of groundwater in the plain area when the amount of water recharged into the shallow groundwater was known.

$$
\begin{gathered}
M_{g} C_{g}=\sum_{i=1}^{m} M_{i} C_{i}, \\
\sum_{i=1}^{m} M_{i}=1,
\end{gathered}
$$

where $M$ and $C$ represent the mass and concentrations of the nitrate per volume of each water body; $g$ represents groundwater; $i=1,2, \ldots m$, represent the different mixing sources.

\section{RESULTS AND DISCUSSION}

\section{General characteristics of water chemistry}

The means of field survey and water chemicals in samples collected from 2008 to 2010 are listed in Table I. The groundwater depth ranged from 1.74 to $15.31 \mathrm{~m}$, and
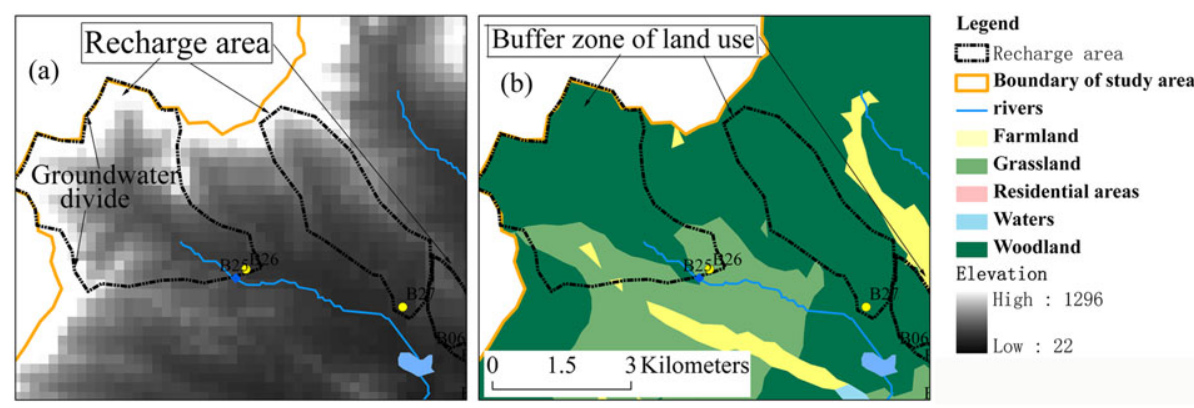

Figure 4. Figures showing examples used to define the areas that supply groundwater recharge to the piezometer upgradient of the groundwater divide. (a) Recharge area of groundwater; (b) buffer zone of land use in recharge area 
Table I. Field survey and major chemical data for samples collected from 2008 to 2010

\begin{tabular}{|c|c|c|c|c|c|c|c|c|c|}
\hline Item & & Sept. 2008 & June 2009 & May 2010 & Item & & Sept. 2008 & June 2009 & May 2010 \\
\hline \multirow[t]{3}{*}{ Depth (m) } & Max. & 15.30 & & 15.31 & \multirow[t]{3}{*}{$\mathrm{Ca}^{2+}\left(\mathrm{mg} \mathrm{l}^{-1}\right)$} & Max. & 174 & 228 & 97 \\
\hline & Min. & 1.83 & & 1.74 & & Min. & 45 & 59 & 32 \\
\hline & Mean & 6.98 & & 7.03 & & Mean & 79 & 87 & 60 \\
\hline \multirow[t]{3}{*}{$\mathrm{pH}$} & Max. & 8.4 & & 8.5 & \multirow[t]{3}{*}{$\mathrm{Mg}^{2+}\left(\mathrm{mgl}^{-1}\right)$} & Max. & 60 & 62 & 33 \\
\hline & Min. & 7.0 & & 7.7 & & Min. & 10 & 11 & 8 \\
\hline & Mean & 7.8 & & 8.0 & & Mean & 31 & 30 & 23 \\
\hline \multirow[t]{3}{*}{$\mathrm{EC}\left(\mu \mathrm{S} \mathrm{cm}^{-1}\right)$} & Max. & 2196 & & 978 & \multirow[t]{3}{*}{$\mathrm{Cl}^{-}\left(\mathrm{mg} \mathrm{l}^{-1}\right)$} & Max. & 166 & 201 & 61 \\
\hline & Min. & 394 & & 234 & & Min. & 13 & 5 & 3 \\
\hline & Mean & 750 & & 619 & & Mean & 35 & 34 & 24 \\
\hline \multirow[t]{3}{*}{$\mathrm{T}\left({ }^{\circ} \mathrm{C}\right)$} & Max. & 24.4 & & 22.4 & \multirow[t]{3}{*}{$\mathrm{NO}_{3}^{-}\left(\mathrm{mg} \mathrm{l}^{-1}\right)$} & Max. & 279 & 313 & 85 \\
\hline & Min. & 13.7 & & 7.3 & & Min. & 6 & 3 & 0 \\
\hline & Mean & 15.9 & & 13.7 & & Mean & 52 & 46 & 25 \\
\hline \multirow[t]{3}{*}{$\mathrm{Na}^{+}\left(\mathrm{mgl}^{-1}\right)$} & Max. & 120.2 & 93.9 & 34.8 & \multirow[t]{3}{*}{$\mathrm{SO}_{4}^{2-}\left(\mathrm{mg} \mathrm{l}^{-1}\right)$} & Max. & 268 & 221 & 93 \\
\hline & Min. & 8.7 & 9.3 & 5.2 & & Min. & 5 & 7 & 0 \\
\hline & Mean & 22.4 & 19.6 & 12.4 & & Mean & 91 & 77 & 54 \\
\hline \multirow[t]{3}{*}{$\mathrm{K}^{+}\left(\mathrm{mg} \mathrm{l}^{-1}\right)$} & Max. & 176.4 & 113.2 & 6.2 & \multirow[t]{3}{*}{$\mathrm{HCO}_{3}{ }^{-}\left(\mathrm{mg} \mathrm{l}^{-1}\right)$} & Max. & 439 & 494 & 306 \\
\hline & Min. & 0.5 & 0.4 & 0.6 & & Min. & 154 & 150 & 144 \\
\hline & Mean & 9.9 & 7.1 & 1.8 & & Mean & 245 & 279 & 206 \\
\hline
\end{tabular}

generally increased from the hilly area to the plains area. The river was dried up in the plains area because of overpumping of groundwater. The $\mathrm{pH}$ ranged from 7.0 to 8.5 , while the mean temperature ranged from $7.3^{\circ} \mathrm{C}$ to $24.4^{\circ}$ C. The EC value had a large range, indicating the existence of pollution at some points. For example, the largest EC values of B11 were 2196 and $978 \mu \mathrm{S} \mathrm{cm}^{-1}$, respectively in 2008 and 2010, indicating contamination source at this point. Species with high concentrations such as $\mathrm{Na}^{+}, \mathrm{K}^{+}, \mathrm{Cl}^{-}, \mathrm{NO}_{3}{ }^{-}$and $\mathrm{SO}_{4}{ }^{2-}$ appeared to be closely related to human-induced sources of pollution such as chemical fertilizers $\left(\mathrm{NH}_{4} \mathrm{NO}_{3},\left(\mathrm{NH}_{4}\right)_{2} \mathrm{SO}_{4}\right.$ and $\left.\mathrm{KCl}\right)$ and manure (Puckett and Cowdery, 2002; Babiker et al., 2004; Kaown et al., 2007). The large concentration ranges for these species suggest that pollution has led to concentrations of human-induced ions at some sites being higher than the natural values, as well as to higher EC values. Moreover, the mean concentrations of these species in September 2008 were larger than those in June 2009 and May 2010, indicating that precipitation will accelerate the leaching of pollutants from the surface after the rainy season. Concentrations of $\mathrm{Ca}^{2+}, \mathrm{Mg}^{2+}$ and $\mathrm{HCO}^{3-}$ did not show similar seasonal variation to those of the human-induced ions, and instead appeared to be associated with geochemical evolution along the flow path. This was because the lithology of the research area is mainly composed of calcite and dolomite.

\section{Nitrate concentration}

The nitrate concentrations and statistical data are shown in Table II and Figure 5, respectively. Overall, $23 \%$ of the samples had nitrate concentrations exceeding the drinking water standard set by the WHO $\left(50 \mathrm{mg} \mathrm{l}^{-1}\right)$, while $79 \%$ of the samples had nitrate concentrations exceeding the standard for the natural environment $\left(13.3 \mathrm{mg}^{-1}\right)$. Comparison of the nitrate concentrations for different sampling periods revealed that the percentage of samples collected in September 2008 with values greater than 50 and $13.3 \mathrm{mgl}^{-1}(30 \%$ and $91 \%$, respectively) was larger than that of samples collected in June 2009 (20\% and 80\%, respectively) and May 2010 (14\% and 55\%, respectively). Correspondingly, the median nitrate concentration of samples collected in September 2008 were larger than those collected in June 2009 and May 2010 (Figure 5). The nitrate concentrations at sites along the flow paths are shown in Figure 6. For most groundwater samples (8 of 11 samples in hill area and 5 of 9 samples in plains area), the nitrate concentrations collected in September 2008 were larger than those collected in June 2009 and May 2010 (exceptions are shown in the orange box in Figure 6). One of the irrigation periods is from March to June, during which time fertilizer was applied to the farmland (Figure 2). The irrigation area was mainly located in the plains area, where the depth of groundwater is greater than $5 \mathrm{~m}$. Contamination and excess fertilizer or manure during the irrigation period at some points might be stored in the soil layer before the rainy season. According to Min et al. (2012), large amounts of precipitation can cause rapid infiltration $\left(3.8-5.8 \mathrm{~mm} \mathrm{~min}^{-1}\right)$ in the hilly area; accordingly, the contamination or excess fertilizer/manure application might have entered the groundwater via heavy rainfall after the rainy season (from June to August). Indeed, this would explain the higher nitrate concentration that was observed in September 2008 for most samples. The datasets for samples collected in September 


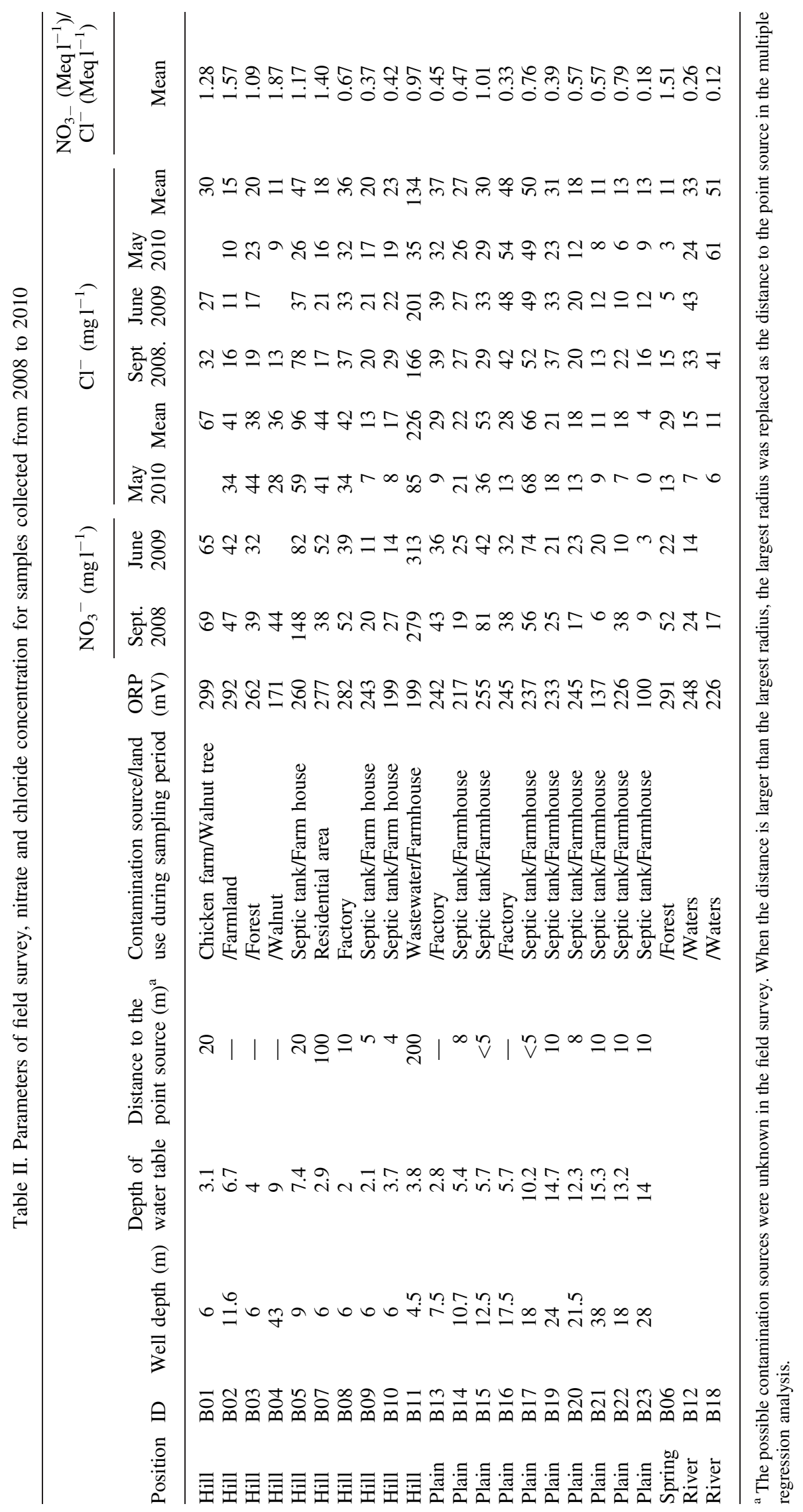




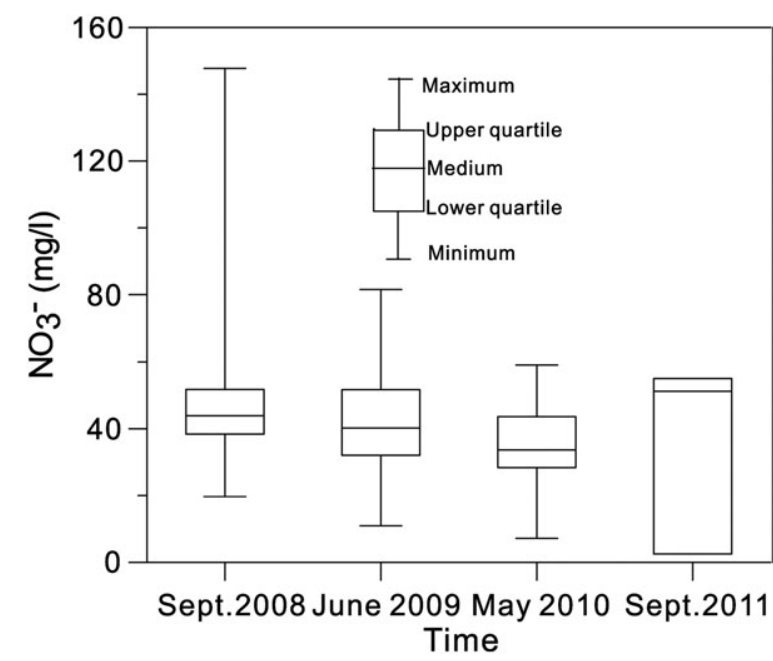

Figure 5. Box-Whisker plot of $\mathrm{NO}_{3}$ concentration in the study area

2008 and that of samples collected in June 2009 and May 2010 were compared to show the influence of heavy rainfall after the rainy season on nitrate concentration. The mean nitrate in groundwater of the hill region varied greatly from 13 to $226 \mathrm{mgl}^{-1}$. These findings indicate that contamination must exist in some sites of the region because the aquifer features and groundwater depth are similar, but the nitrate input is different at different sampling sites (Figure 6). For example, the groundwater depths of B14 and B15 are 7.6 and $7.3 \mathrm{~m}$, respectively; however, the average nitrate increased from $22 \mathrm{mgl}^{-1}$ at B14 to $53 \mathrm{mg} \mathrm{l}^{-1}$ at B15, which is located close to a septic tank. These findings suggest that the distance to the point source had an impact on the groundwater nitrate concentration. The variation among nitrate concentrations at the different sampling periods in the plain area was not as obvious as that in hilly area because many geographic factors can affect nitrate levels in groundwater in the watershed. Yuan et al. (2011) reported that the groundwater originated from precipitation based on the stable isotopes of oxygen and hydrogen in the same research area. The nitrate concentrations and $\mathrm{EC}$ values of most samples decreased with increasing groundwater depth along the flow path from the hill area to the plains area (Figure 7), suggesting that pollution from the surface was the major reason for the high nitrate concentrations as well as the EC values of groundwater. Some samples collected from wells of shallow depths contained low nitrate concentrations, which might reflect the natural background value of the soil.

\section{Time and source of groundwater recharge}

The CFC concentrations are given in Table III. CFC-11 showed a greater propensity for degradation (Busenberg et al., 1993). Additionally, CFC-11 is commonly found in groundwater as a result of local contamination, e.g. from refrigerators and landfills (Goody et al., 2006). The

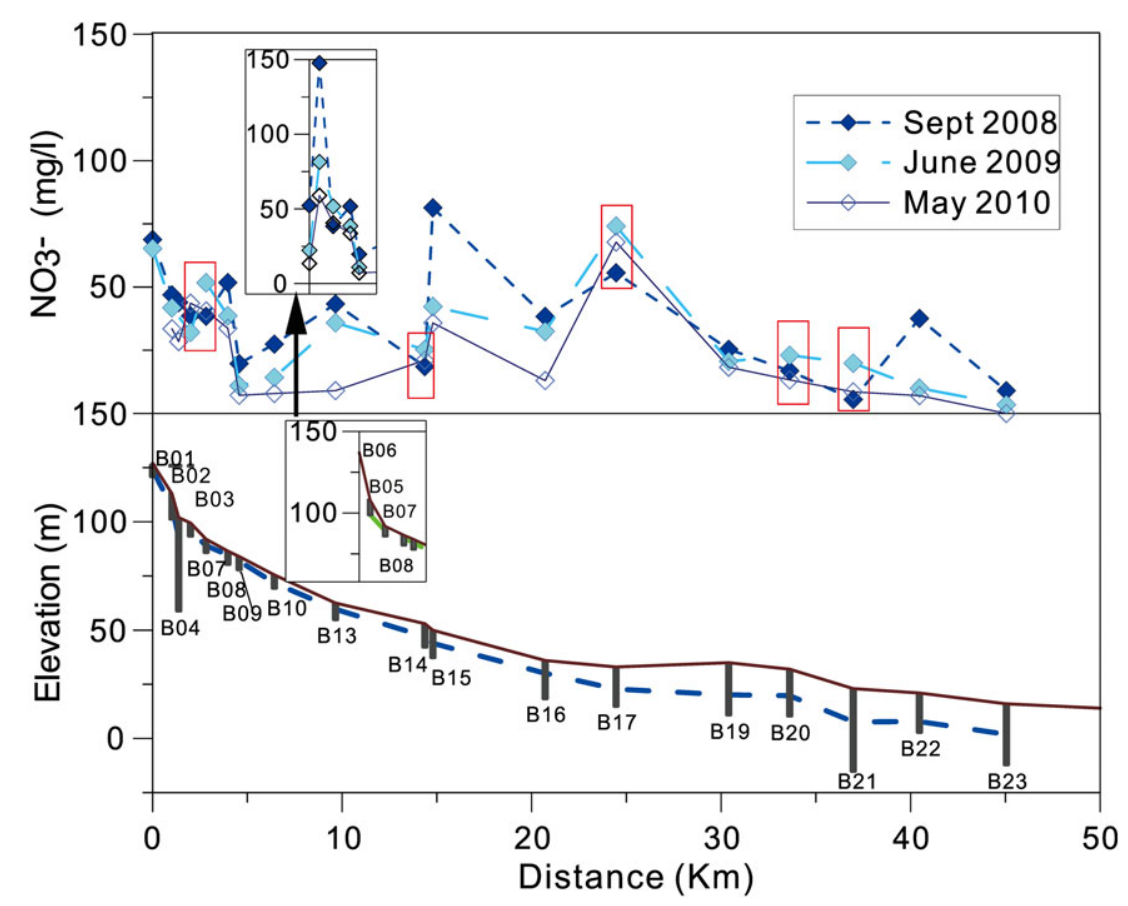

Figure 6. Variation of nitrate contamination in groundwater along the flow path (Figure 3). Piezometers B06 to B05 are located in a valley, which has groundwater flow direction that differs from that for piezometers B01 to B07. The inset for piezometers B06 to B07 shows the variation of elevation and nitration concentration with groundwater flow direction. The water table of groundwater is based on the average values for 2008 and 2010 

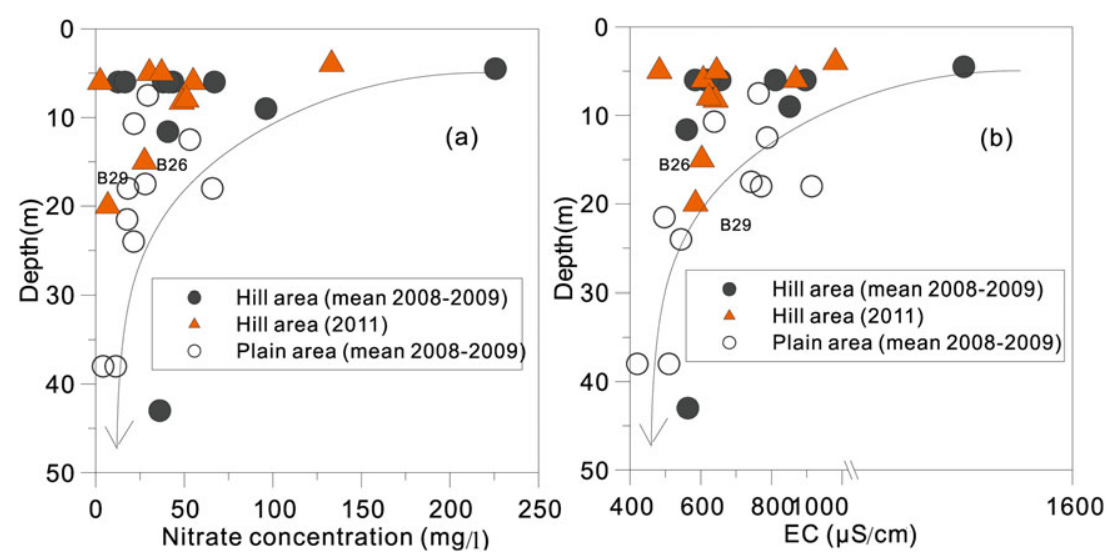

Figure 7. Variations in groundwater nitrate levels and EC values with depth

Table III. Mixing fraction of young water based on the binary mixing model

\begin{tabular}{lccccc}
\hline ID & Well depth (m) & CFC-12 (pptv) & CFC-113 (pptv) & Recharge time of mixing water & Mixing fraction of young groundwater \\
\hline B27 & 4 & 176.50 & 15.91 & 1982 & 0.47 \\
B26 & 15 & 242.33 & 33.62 & 1990 & 0.5 \\
B09 & 6 & 188.1 & 10.5 & 1974 & 1 \\
B08 & 6 & 157.21 & 20.61 & 1990 & 0.68 \\
B06-2 & 5 & 210 & 14.7 & 1978 & 1 \\
B02-2 & 8.25 & 196.87 & 21.45 & 1985 & 0.51 \\
B02 & 8 & 210 & 18.2 & 1982 & 0.37 \\
B29 & 15 & $970.2^{\mathrm{a}}$ & 20.7 & &
\end{tabular}

${ }^{a}$ Sample was polluted.

${ }^{\mathrm{b}}$ B06-2 and B02-2 are samples collected near to points B06 and B02, respectively.

concentrations of CFC-11 exceeded the limit of age estimation, indicating possible contamination; therefore, CFC-12 and CFC-113 were used to determine the groundwater age of the hill area. The CFC-12 and CFC-113 values only agreed well between two samples (B09 and B06-2). It was estimated that the groundwater at B09 and B06-2 was recharged by precipitation in 1974 and 1978 according to the piston flow model. The differences between CFC-12 and CFC-113 estimated for the other samples ranged from 4 to 6 a based on the CFC concentrations. The ORP of groundwater samples in the hill area ranged from 243 to $299 \mathrm{mV}$, except for samples B04 and B10, indicating an aerobic environment (Table II). The aerobic environment was also verified in a previous study conducted by Wang et al. (2013). Because CFC degradation under aerobic conditions is unlikely Han et al. (2012), the binary groundwater mixing approach based on analysis of the multiple CFCs (Plummer et al., 2006) was applied to interpret variations in physical and chemical parameters. Also, it has been reported that binary mixing of young water with old (pretracer) water is one of the simplest model to consider and is perhaps the most important in many fractured-rock environments (Bockgard et al., 2004). Figure 8 shows

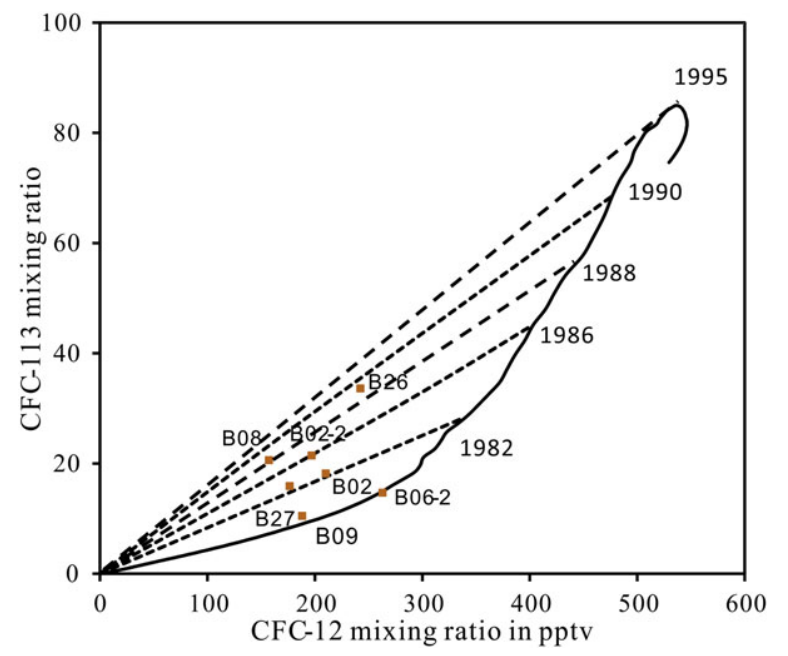

Figure 8. Binary mixing model ideal curves based on CFC-113 and CFC12 concentrations in groundwater

the simplest binary mixing model, which employed a mixture of two end-members with atmospheric CFC concentrations. The mixing fraction of young water based on the binary mixing model is listed in Table III. One end-member is a given recharge date (e.g. young 
water in 1990, 1985 and 1982) derived from a pistonflow model study, while the other consists of water containing low levels of CFCs. The fraction of young water was estimated according to the position on the two end-member mixing lines (Plummer et al., 2006). For example, B26 and B08 show the location of a 1:1 and 0.68:0.32 mixture of water recharged in 1990 with old, low CFCs water, respectively (Table III). However, the concentrations of CFC-12 of B29 exceeded the limit of age estimation, suggesting it has been polluted. The old, low CFCs water might have been from areas recharged before 1950 or 1940, when there was little nitrate pollution caused by anthropogenic activities. Overall, the results showed that young water originated from 1974 to 1990 , indicating that variations in land use during this period might affect nitrate contamination in groundwater.

CFCs in the hill area also showed that the groundwater originated from precipitation, which is in accordance with previous studies based on hydrogen and oxygen isotopes (Song et al., 2011; Yuan et al., 2011). However, it has been argued that it may be difficult to receive direct precipitation recharge in alluvial fan/plains areas because of the deep groundwater depth caused by over-exploitation (Chen et al., 2004; Aji et al., 2008; Li et al., 2008; Lu et al., 2008; Yuan et al., 2012). A normal fault is buried under the alluvial aquifer in the plains area. The groundwater of the plains area has also been shown to be recharged by fracture water flowing upward through the fault and lateral groundwater from mountainous and hill regions (Yuan et al., 2011). Additionally, an average infiltration rate of precipitation of $3.8 \pm 0.8 \mathrm{~mm} / \mathrm{a}$ has been estimated for the plains area of the Beiyishui River watershed using the stable isotopes and chloride in the unsaturated profile (Yuan et al., 2012). Consequently, the fate of nitrate in the groundwater of the plains area will be discussed without consideration of the land surface conditions. Variations in nitrate along the groundwater flow path are discussed in the next section.

\section{Factors affecting nitrate distribution based on multiple regression analysis}

Multiple regression analysis was conducted using the STATISTIC software to identify factors contributing to nitrate contamination in the hill area. Land use in 1980, 1995 and 2000 revealed that variations primarily occurred in woodland and grassland areas (Figure 3). Specifically, planting of trees from 1980 to 1995 resulted in replacement of the majority of grassland in the hill area. It was also assumed that there were no large variations in land use from 1974 to 1980 . Therefore, land use in 1980 was considered to reflect the surface conditions at B09 and B06-2, where CFC data showed that the groundwater recharge occurred in 1974 and 1978, respectively. For other samples, the land use at the recharge time was calculated by Equation 4 using the linear interpolation method, after which the percentage of land use in the buffer area was calculated. Because calculation of the buffer area considered the influence of aquifer features, the percentage of farmland, woodland, grassland and residential area, depth of groundwater and distance from the point sources were selected to conduct multiple regression analysis.

The results of multiple regressions are shown in Table IV. The results showed that the distance to the point source and the woodland was significantly correlated with the nitrate concentration in groundwater of the study area ( $p$-value $<0.0001$ and $p$-value $=0.01$, respectively). In the hill area, point source pollution contributed greatly to the nitrate concentration in groundwater. For example, B01 (mean nitrate $67 \mathrm{mgl}^{-1}$ ) was near a chicken farm, B11 (mean nitrate $226 \mathrm{mgl}^{-1}$ ) was collected from near a wastewater discharging point and B05, B15 and B17 (mean nitrate 96, 53 and $66 \mathrm{mgl}^{-1}$, respectively) were obtained from areas near rural septic tank. As discussed above, the land use from 1974 to 1990 affected nitrate input in this region. Additionally, a portion of grassland present in 1980 was transformed into woodland in 1995.

Table IV. Parameter estimates for the multiple regression model based on land use, groundwater depth and distance from pollution source in the hill area

\begin{tabular}{|c|c|c|c|c|c|c|}
\hline \multirow[b]{2}{*}{$N=15$} & \multicolumn{2}{|c|}{ Unstandardized coefficients } & \multicolumn{2}{|c|}{ Standardized coefficients } & \multirow{2}{*}{$\mathrm{t}(9)$} & \multirow{2}{*}{$p$-Value } \\
\hline & $\mathrm{B}$ & Std. error & Beta & Std. error & & \\
\hline Intercept & & $(21.95)$ & 134.14 & $(0.16)$ & 0.87 & \\
\hline Distance to point source & 0.94 & 0.19 & 0.40 & 0.08 & 5.02 & $<0.0001$ \\
\hline Converted woodland $^{\mathrm{a}}$ & 0.47 & 0.24 & 16.52 & 8.26 & 2.00 & 0.01 \\
\hline Farmland & 0.66 & 4.00 & 22.48 & 136.10 & 0.17 & 0.87 \\
\hline Permanent woodland & 0.08 & 1.15 & 8.99 & 137.39 & 0.07 & 0.95 \\
\hline Depth & 0.07 & 0.17 & 0.17 & 0.44 & 0.39 & 0.71 \\
\hline
\end{tabular}

${ }^{\text {a }}$ A portion of the grassland was converted into woodland (Agricultural forest) during the groundwater recharge time. 
In the study area, the major planted forests include Chinese pine, oriental arborvitae, locust and poplar (Cui, 2011). Fertilization is the main treatment used for cultivation of planted forests, especially for agricultural woodlands (Zhao et al., 2012), and reasonable fertilization is known to improve the quality and quantity of seedlings. Although fertilizers could also have been applied to farmland areas, multiple regression did not indicate a significant correlation between farmland and nitrate concentration. As shown in Figure 3, woodland replaced farmland as the major land use type in 1995. Moreover, the buffer zone for most samples in the hill region was defined as the area surrounding the piezometer and encompassed all areas or features that supply groundwater recharge to the piezometer upgradient to the groundwater divide. Another possible reason is that the woodland has entered into the stage of nitrogen saturation, resulting in leaching of nitrate from soils to groundwater via nitrification (Aber et al., 1989). Overall, these results indicate that the nitrate concentration in groundwater of the hilly region was also influenced by the land use change from grassland to artificial planting of woods from 1980 to 1990 .

The contribution of point source pollution to the high nitrate concentration in the hill region also can be verified by nitrate isotopes $\left(\delta^{15} \mathrm{~N}\right)$ at several sites. For example, the $\delta^{15} \mathrm{~N}$ values of B02, B08, B25 and B28 collected in 2011 in the hill region ranged from 10.4 to $16.76 \%$, suggesting that nitrate primarily originated from manure or sewage pollution. The $\delta^{15} \mathrm{~N}$ values at B01 were $5.4 \%$ o and $7.04 \%$ in 2008 and 2009, respectively, which are slightly higher than the $\delta^{15} \mathrm{~N}$ values of soil and fertilizer. Application of fertilizer in the walnut tree land and mixture of manure from a chicken farm were responsible for the $\delta^{15} \mathrm{~N}$ values and the high nitrate concentration (mean, $67 \mathrm{mgl}^{-1}$ ). The $\delta^{15} \mathrm{~N}$ value of $\mathrm{B} 02$ collected in 2008 was $6.68 \%$, also suggesting a mixed source of fertilizer and manure. The $\delta^{15} \mathrm{~N}$ values of B06 and B06-2 with high nitrate concentrations after precipitation (September 2011) were 5.02 and $4.44 \%$ o, respectively, suggesting that they originated from fertilizer. The possible sources, including fertilizer and manure in the hill region, were also analysed by our previous study (Wang et al., 2013).

In the plains area, nitrate transformation was controlled by groundwater flow to a great extent. Figure 9 is a cross plot showing the $\mathrm{NO}_{3}-\mathrm{Cl}$ ratios for all samples in the study area. The linearity relationship between nitrate and chloride concentration by Pearson correlation analysis $\left(p=0.002, R^{2}=0.503\right)$ for all points in the hill area indicated the common sources for these sites. $\mathrm{NO}_{3}-\mathrm{Cl}$ ratios in the hill region were rather stable and higher for most points except for B09, B10 and B29 in hilly areas than in plain areas (Table II). $\mathrm{NO}_{3}-\mathrm{Cl}$ ratios for points

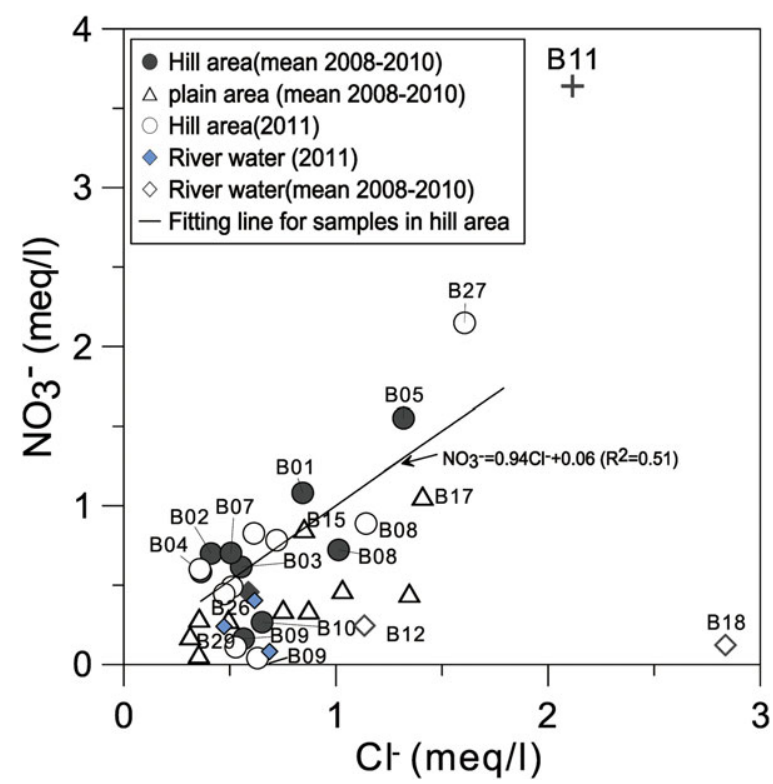

Figure 9. Nitrate and chloride ratios for all samples in the study area

B09, B10 and B29, as well as the river water collected in 2011 were lowest of all samples in the hilly areas. River water seeps through the streambed and recharges the shallow groundwater near sites of B09 and B10 which has been discussed by Yuan et al. (2011) combining stable isotopes with temperature. B29 was close to the Wanglong River, where the depth to the water table was $9.9 \mathrm{~m}$ during sampling period. The similar distribution of these samples and river water samples in Figure 9 also showed that there were hydraulic interactions between the groundwater and the river at these sites. The high $\mathrm{NO}_{3}$ (mean $226 \mathrm{mgl}^{-1}$ ) and $\mathrm{Cl}$ (mean $134 \mathrm{mgl}^{-1}$ ) concentrations of $\mathrm{B} 11$, implied that it received excessive nitrate input. The nitrate decreased along the flow path of the plains area, indicating a mixture effect of freshwater with low nitrate concentration. Yuan et al. (2011) demonstrated that groundwater in the plains area was a mixture of fracture water flowing upward through the fault and groundwater in the hilly area. That means it is difficult for the surface nitrate to leach and recharge into groundwater. Therefore, the nitrate in groundwater of plains area was also mainly sourced from lateral groundwater of the hilly area and fracture water. As pointed out in previous studies, there is little nitrogen input from precipitation owing to the recharge rate of precipitation and because fracture water may be recharged by water with low nitrate. Therefore, the contributions of mixture and denitrification were estimated based on the estimated mixture ratios (Yuan et al., 2011) for points B17 to B23 in this study. The mean nitrate in groundwater in the hill area $\left(64 \mathrm{mg}^{-1}\right)$ was defined as the initial nitrate concentration flowing into the plains area. The nitrate concentration of B20 $\left(18 \mathrm{mgl}^{-1}\right)$ was 
Table V. Contributions of mixture and denitrification effects to decreasing nitrate concentration in the plains area

\begin{tabular}{|c|c|c|c|c|c|c|}
\hline \multirow[b]{2}{*}{ ID } & \multirow{2}{*}{$\begin{array}{c}\text { Fraction of } \\
\text { fracture water }\end{array}$} & \multirow{2}{*}{$\begin{array}{c}\text { Observed } \\
\text { concentration } \\
\left(\mathrm{mg} \mathrm{l}^{-1}\right)\end{array}$} & \multicolumn{2}{|c|}{ Calculated value by mixture fraction } & \multicolumn{2}{|c|}{ Amount of decrease because of denitrification } \\
\hline & & & Concentration $\left(\mathrm{mg} \mathrm{l}^{-1}\right)$ & Percentage $(\%)$ & Concentration $\left(\mathrm{mg} \mathrm{l}^{-1}\right)$ & Percentage $(\%)$ \\
\hline B17 & 0.44 & 65.8 & 43.7 & 31 & & \\
\hline B19 & 0.71 & 21.4 & 31.3 & 51 & 9.9 & 16 \\
\hline B20 & 1 & 17.7 & 18.0 & 72 & 0.3 & 0.5 \\
\hline $\mathrm{B} 21$ & 0.97 & 11.3 & 19.4 & 70 & 8.1 & 13 \\
\hline $\mathrm{B} 22$ & 0.5 & 18.2 & 41.0 & 36 & 22.8 & 36 \\
\hline $\mathrm{B} 23$ & 0.6 & 4.1 & 36.4 & 43 & 32.3 & 51 \\
\hline
\end{tabular}

${ }^{\mathrm{a}}$ The fraction was referenced according to Yuan et al. (2011).

defined as the mixed fracture water concentration. The material balance model is applied to calculate the nitrate concentration mixed by fracture water and groundwater in the hill area.

The calculated nitrate concentrations are listed in Table V. The difference between the observed and calculated concentration was ascribed to denitrification. The results revealed that mixture with freshwater was the main reason for the decreasing nitrate, with a contribution ranging from 31 to $72 \%$. Denitrification increased with distance from the fracture site. For example, denitrification accounted for $51 \%$ of the decrease of nitrate at B23, where the ORP was $100 \mathrm{mV}$, indicating a reduction condition. Because denitrification can result in the increase of the nitrate isotopes, the high $\delta^{15} \mathrm{~N}$ in this area $(19.5 \%$ ) (Wang et al., 2013) verified the occurrence of the denitrification in the plains area.

\section{SUMMARY AND CONCLUSIONS}

In this study, the spatial and temporal distribution characteristics of nitrate and the influencing factors in the groundwater recharge area of the NCP were discussed based on land use, CFCs and hydrochemical data. Some parts of this paper are from the $\mathrm{PhD}$ thesis written by Wang (2014) who is the first author of this paper. The multiple regression method was used to analyse factors contributing to the nitrate concentrations in groundwater. The land use during the recharge year determined based on the groundwater age estimated from the CFCs was employed to investigate possible factors.

Overall, $23 \%$ of groundwater samples exceeded the nitrate standard for drinking water $\left(50 \mathrm{mg} \mathrm{l}^{-1}\right.$, WHO), while $79 \%$ of the samples exceeded the natural environment standard $\left(13.3 \mathrm{mgl}^{-1}\right)$, indicating that these samples have been impacted by anthropogenic activities. CFCs data in the hill area showed that most of groundwater was recharged by a mixture of young water from 1982 to 1990 and old water before 1950s.
Therefore, the land use of the recharge time was employed as one of the factors in the multiple regression analysis, while groundwater depth and distance to point sources were taken to indicate the extent to which these factors affected the nitrate concentration in groundwater. The results of the multiple regression analysis showed that point-source pollution was the most significant factor leading to high nitrate concentrations in groundwater. Additionally, application of fertilizer for the agricultural woodland from 1980 to 1990 had an impact on nitrate contamination in groundwater of the hill area. In the plains area, the nitrate concentration decreased along the flow path in the plains area, and a mixture effect accounted for 31 to $72 \%$ of the decrease in nitrate concentration, while denitrification was responsible for as much as $51 \%$ of the decrease.

The case study area is located in the transition zone from mountain to plain area. It delegates a $10.2 \times 10^{4} \mathrm{~km}^{2}$ area of agro-forest ecology system where the anthropogenic activities are concentrated in the hilly area, the recharge area of NCP. The previous researches related to the nitrate contamination in groundwater were all focused on that in the plain area and there were almost no study in the hilly area was reported. Our results first revealed that the nitrate contamination existed in the hilly region which should be paid much more attention to prevent the groundwater in the plains areas from deterioration. Multiple regression analysis showed that the high nitrate concentrations in groundwater in the hill region of North China were closely related to point source pollution from facilities such as rural septic systems and sewage discharge in the rural residence area. Considering the recharge time of groundwater, the groundwater nitrate concentration had no direct relationship with land use at the sampling time, but did have a significant relationship with land use at the recharge time in the hill region. Current land use management strategies should take into account the fertilizer input and load with different land use to prevent the nitrate contamination in the future. 


\section{ACKNOWLEDGEMENTS}

This study was financially supported by the 100-Talent Project of Chinese Academy of Sciences and the Key Program of the National Natural Science Foundation of China (No. 41471028, No.41101033). The authors greatly thank reviewers for their good comments and suggestions regarding this manuscript. The authors also thank language editors from Edanz cooperation for their help on the English expression.

\section{REFERENCES}

Aber JD, Nadelhoffer KJ, Steudler P, Melillo JM. 1989. Excess nitrogen from fossil fuel combustion may stress the biosphere. BioScience 39: 378 .

Aji K, Tang C, Song X, Kondoh A, Sakura Y, Yu J, Kaneko S. 2008. Characteristics of chemistry and stable isotopes in groundwater of Chaobai and Yongding River basin, North China Plain. Hydrological Processes 22: 63-72.

Babiker IS, Mohamed MA, Terao H, Kato K, Ohta K. 2004. Assessment of groundwater contamination by nitrate leaching from intensive vegetable cultivation using geographical information system. Environment International 29: 1009-1017.

Barringer T, Dunn D, Battaglin W, Vowinkel E. 1990. Problems and methods involved in relating land use to ground-water quality1. Journal of the American Water Resources Association 26: 1-9.

Bockgard N, Rodhe A, Olsson KA. 2004. Accuracy of CFC groundwater dating in a crystalline bedrock aquifer: data from a site in southern Sweden. Hydrogeology Journal 12: 171-183.

Broers HP. 2004. The spatial distribution of groundwater age for different geohydrological situations in the Netherlands: implications for groundwater quality monitoring at the regional scale. Journal of Hydrology 299: 84-106.

Burkart MR, Kolpin DW. 1993. Hydrologic and land-use factors associated with herbicides and nitrate in near-surface aquifers. Journal of Environmental Quality 22: 646-656.

Busenberg E, Plummer LN. 2000. Dating young groundwater with sulfur hexafluoride: natural and anthropogenic sources of sulfur hexafluoride. Water Resources Research 36: 3011-3030.

Busenberg E, Weeks EP, Plummer LN, Bartholomay RC. 1993. Age dating ground water by use of chlorofluorocarbons $(\mathrm{CCl} 3 \mathrm{~F}$ and $\mathrm{CCl} 2 \mathrm{~F} 2$ ), and distribution of chlorofluorocarbons in the unsaturated zone, Snake River plain aquifer, Idaho National Engineering Laboratory, Idaho. US Department of Interior, US Geological Survey.

Cao Y, Tang C, Song X, Liu C, Zhang Y. 2013. Residence time as a key for comprehensive assessment of the relationship between changing land use and nitrates in regional groundwater systems. Environmental Science: Processes and Impacts 15: 876-885.

Chen J, Tang C, Sakura Y, Kondoh A, Yu J, Shimada J, Tanaka T. 2004. Spatial geochemical and isotopic characteristics associated with groundwater flow in the North China Plain. Hydrological Processes 18: 3133-3146.

Chen J, Tang C, Sakura Y, Yu J, Fukushima Y. 2005. Nitrate pollution from agriculture in different hydrogeological zones of the regional groundwater flow system in the North China Plain. Hydrogeology Journal 13: 481-492.

Chen J, Tang C, Yu J. 2006. Use of $<\sup >18</$ sup $>0,<\sup >$ $2</$ sup $>\mathrm{H}$ and $<\sup >15</$ sup $>\mathrm{N}$ to identify nitrate contamination of groundwater in a wastewater irrigated field near the city of Shijiazhuang, China. Journal of Hydrology 326: 367-378.

Cui H. 2011. Analysis on effect of agriculture non-point source pollution on the water environment in Baiyangdian Basin. Xiandai Nongye Keji 7: 298-230. (In Chinese)

Currell MJ, Han D, Chen Z, Cartwright I. 2012. Sustainability of groundwater usage in northern China: dependence on palaeowaters and effects on water quality, quantity and ecosystem health. Hydrological Processes 26: 4050-4066.
Darcy H. 1856. Les fontaines publiques de la ville de Dijon. V. Dalmont. Devito K, Creed I, Rothwell R, Prepas E. 2000. Landscape controls on phosphorus loading to boreal lakes: implications for the potential impacts of forest harvesting. Canadian Journal of Fisheries and Aquatic Sciences 57: 1977-1984.

Dinnes DL, Karlen DL, Jaynes DB, Kaspar TC, Hatfield JL, Colvin TS, Cambardella CA. 2002. Nitrogen management strategies to reduce nitrate leaching in tile-drained Midwestern soils. Agronomy Journal 94: 153-171.

Eckhardt DA, Stackelberg PE. 1995. Relation of ground-water quality to land use on Long Island, New York. Ground Water 33: 1019-1033.

Fenton O, Richards KG, Kirwan L, Khalil MI, Healy MG. 2009. Factors affecting nitrate distribution in shallow groundwater under a beef farm in South Eastern Ireland. Journal of Environmental Management 90: 3135-3146.

Freeze RA, Cheery JA. 1979. Groundwater. Prentice-Hall Inc.: Englewood Cliffs, New Jersey; 604.

Gao B. 2005. Hydrogeological conditions and water chemical characteristics of the main thermal stratum in North China Plain. pp: 166-174. (In Chinese)

Gardner KK, Vogel RM. 2005. Predicting ground water nitrate concentration from land use. Ground Water 43: 343-352.

Gooddy L, Abesser C, Lapworth DJ. 2006. Using chlorofluorocarbons (CFCs) and sulphur hexafluoride (SF 6) to characterise groundwater movement and residence time in a lowland Chalk catchment. Journal of hydrology 330: 44-52.

Han L, Hacker P, Gröning M. 2007. Residence times and age distributions of spring waters at the Semmering catchment area, Eastern Austria, as inferred from tritium, CFCs and stable isotopes. Isotopes in Environmental and Health Studies 43: 31-50.

Han D, Song X, Currell MJ, Tsujimura M. 2012. Using chlorofluorocarbons (CFCs) and tritium to improve conceptual model of groundwater flow in the South Coast Aquifers of Laizhou Bay, China. Hydrological Processes 26: 3614-3629.

Kaneko S, Kondoh A, Shen Y, Tang C. 2005. The relation among the water cycle, grain production and anthropogenic activities in the North China Plain. Journal of the Japan Society of Hydrology \& Water Resources 18: 575-583.

Kaown D, Hyun Y, Bae G-O, Lee K-K. 2007. Factors affecting the spatial pattern of nitrate contamination in shallow groundwater. Journal of Environmental Quality 36: 1479-1487.

Kolpin DW. 1997. Agricultural chemicals in groundwater of the midwestern United States: relations to land use. Journal of Environmental Quality 26: 1025-1037.

Kralic M, Humer F, Fank J, Harum T, Klammler G, Gooddy D, Sültenfuß J, Gerber C, Purtschert R. 2014. Using 18O/2H, 3H/3He, $85 \mathrm{Kr}$ and $\mathrm{CFCs}$ to determine mean residence times and water origin in the Grazer and Leibnitzer Feld groundwater bodies (Austria). Applied Geochemistry 50: 150-163.

Li F, Pan G, Tang C, Zhang Q, Yu J. 2008. Recharge source and hydrogeochemical evolution of shallow groundwater in a complex alluvial fan system, southwest of North China Plain. Environmental Geology 55: 1109-1122.

Lie Y, Zhen W, ShengWei Z, HongJun L, Gilkes R. 2010. Assessment of potential risk of nitrate leaching on agriculture region using Arc-NLEAP model. In: Proceedings of the 19th World Congress of Soil Science: Soil solutions for a changing world, Brisbane, Australia, 1-6 August 2010., International Union of Soil Sciences (IUSS), c/o Institut für Bodenforschung, Universität für Bodenkultur, pp: 30-33.

Lu Y, Tang C, Chen J, Song X, Li F, Sakura Y. 2008. Spatial characteristics of water quality, stable isotopes and tritium associated with groundwater flow in the Hutuo River alluvial fan plain of the North China Plain. Hydrogeology Journal 16: 1003-1015.

MacDonald AM, Darling WG, Ball DF, Oster H. 2003. Identifying trends in groundwater quality using residence time indicators: an example from the Permian aquifer of Dumfries, Scotland. Hydrogeology Journal 11: 504-517.

McLay C, Dragten R, Sparling G, Selvarajah N. 2001. Predicting groundwater nitrate concentrations in a region of mixed agricultural land use: a comparison of three approaches. Environmental Pollution 115: 191-204. 
Min L, Yu J, Song R, Hu S, Hu K, Zhang G. 2012. Infiltration characteristics under simulated rainfall over platycladus orientalis land in Taihang mountainous region. Journal of Soil and Water Conservation 24. (In Chinese)

Moore KB, Ekwurzel B, Esser BK, Hudson GB, Moran JE. 2006. Sources of groundwater nitrate revealed using residence time and isotope methods. Applied Geochemistry 21: 1016-1029.

Plummer LN, Busenberg E, Cook PG. 2006. Principles of chlorofluorocarbon dating. In: Use of chlorofluorocarbons in hydrology - a guidebook. International atomic energy agency: Vienna; 17-29(Chapter13).

Puckett LJ, Cowdery TK. 2002. Transport and fate of nitrate in a glacial outwash aquifer in relation to ground water age, land use practices, and redox processes. Journal of Environmental Quality 31: 782-796.

Rashid M, Voroney R. 2005. Field-scale application of oily food waste and nitrogen fertilizer requirements of corn at different landscape positions. Journal of Environmental Quality 34: 963-969.

Shen Y, Lei H, Yang D, Kanae S. 2011. Effects of agricultural activities on nitrate contamination of groundwater in a Yellow River irrigated region. IAHS-AISH publication: 73-80.

Song X, Wang P, Yu J, Liu X, Liu J, Yuan R. 2011. Relationships between precipitation, soil water and groundwater at Chongling catchment with the typical vegetation cover in the Taihang mountainous region, China. Environmental Earth Sciences 62: 787-796.

Spalding RF, Exner ME. 1993. Occurrence of nitrate in groundwater-a review. Journal of Environmental Quality 22: 392-40.

Stadler S, Osenbrück K, Knöller K, Suckow A, Sültenfuß J, Oster H, Himmelsbach T, Hötzl H. 2008. Understanding the origin and fate of nitrate in groundwater of semi-arid environments. Journal of Arid Environments 72: 1830-1842.

Tang C, Chen J, Shen Y. 2004. Long-term effect of wastewater irrigation on nitrate in groundwater in the North China Plain. IAHS PublicationsSeries of Proceedings and Reports 285: 34-40.

Tang C, Chen J, Song X, Zhang W. 2006. Effects of wastewater irrigation on groundwater quantity and quality in the suburbs of Shijiazhuang city. China, 1.

USDA. 2003. Market and trade economics division, U.S. Department of Agriculture., Agriculture Information Bulletin Number.

Wang S. 2014. Study on water cycle, hydrogeochemical evolution and nitrate contamination in Lake Baiyangdian watershed, North China Plain. $\mathrm{PhD}$ thesis. Chiba University.
Wang S, Tang C, Song X, Yuan R, Wang Q, Zhang Y. 2013. Using major ions and $\delta 15 \mathrm{~N}-\mathrm{NO} 3$-to identify nitrate sources and fate in an alluvial aquifer of Baiyangdian lake watershed, North China Plain. Environmental Science: Processes and Impacts 15: 1430-1443.

Wang S, Tang C, Song X, Wang Q, Zhang Y, Yuan R. 2014. The impacts of a linear wastewater reservoir on groundwater recharge and geochemical evolution in a semi-arid area of the Lake Baiyangdian watershed, North China Plain. Science of the Total Environment 482: 325-335.

Xu J. 2004. A study of anthropogenic seasonal rivers in China. Catena 55: 17-32.

Yuan R, Song X, Zhang Y, Han D, Wang S, Tang C. 2011. Using major ions and stable isotopes to characterize recharge regime of a faultinfluenced aquifer in Beiyishui River Watershed, North China Plain. Journal of Hydrology 405: 512-521.

Yuan R, Song X, Han D, Zhang Y, Zhang L, Zhang B, Long X, Yu Y. 2012. Rate and historical change of direct recharge from precipitation constrained by unsaturated zone profiles of chloride and oxygen-18 in dry river bed of North China Plain. Hydrological Processes 26: 1291-1301.

Zhang W, Tian Z, Zhang N, Li X. 1996. Nitrate pollution of groundwater in northern China. Agriculture, Ecosystems \& Environment 59: 223-231.

Zhang Z, Fei Y, Chen Z, Shi J. 2009. Investigation and assessment of the sustainable use of groundwater in North China Plain. Geological Publishing House. (In Chinese)

Zhang C-Y, Zhang S, Yin M-Y, Ma L-N, He Z, Ning Z. 2013. Nitrogen isotope studies of nitrate contamination of the thick vadose zones in the wastewater-irrigated area. Environmental Earth Sciences 68: $1475-1483$.

Zhao Z. 2013. Simulation study of TN load in Baiyangdian basin based on the SWAT model. Water Sciences and Engineering Technology 003: 33-37. (In Chinese)

Zhao Y, Xia X, Yang Z, Wang F. 2012. Assessment of water quality in Baiyangdian Lake using multivariate statistical techniques. Procedia Environmental Sciences 13: 1213-1226.

Zhu Z, Chen D. 2002. Nitrogen fertilizer use in China-contributions to food production, impacts on the environment and best management strategies. Nutrient Cycling in Agroecosystems 63: 117-127. (In Chinese) 